\title{
Insect Pollinators of Sesame and the Effect of Entomophilous Pollination on Seed Production in New Alluvial Zone of West Bengal
}

\author{
Rakesh Das* and Shantanu Jha \\ Department of Agricultural Entomology, Bidhan Chandra KrishiViswavidyalaya \\ Mohanpur, Nadia, West Bengal, India, PIN- 741252 \\ *Corresponding author
}

\begin{tabular}{l}
\hline Ke y w o r d s \\
$\begin{array}{l}\text { Sesame, Insect } \\
\text { pollinators, } \\
\text { Abundance, Honey } \\
\text { bees, Yield }\end{array}$ \\
\hline Article Info \\
\hline $\begin{array}{l}\text { Accepted: } \\
\text { 12 February } 2019 \\
\text { Available Online: } \\
\text { 10 March } 2019\end{array}$ \\
\hline
\end{tabular}

\section{Introduction}

Pollination is an important step in the seeds production of all spermatophytes (seed plants), resulting in the production of offspring that are genetically diverse (Dafni et al., 2005). The well-established association between insects and flowers make them one of the major groups of pollinating agents. Of the total pollination activities, over $80 \%$ is performed by insects and among them bees are considered as the best pollinators (Robinson and Morse, 1989). It is reported that one third of the total human food supply relies on insect pollination (Jivan, 2013; Said et al., 2015). The major pollinating insects of different crops mainly belong to the orders Hymenoptera, Diptera, Coleoptera, 
Lepidoptera, Thysanoptera, Hemiptera and Neuroptera (Free, 1993; Kearns et al., 1998; Mitra and Parui, 2002; Mitra et al., 2008).

In India sesame (Sesamumindicum L.) ranks third after Groundnut and Mustard among the major nine oil seed crops. The flower structure of sesamum facilitates cross pollination, even though the crop is usually considered as selfpollinating (Yermanos, 1980; Ashri, 2007 and Sarker, 2004). The range of cross-pollination varies in between $0.5 \%$ to $65 \%$ depending upon insect activity, environmental conditions and availability of other vegetation (Kumar and Lenin, 2000).

Though most of the oil seed crops are cross pollinated still adequate pollination is vital for significant increase in seed production especially by the utilization of honeybee as effective pollinators. Both in open pollination and bee pollination treatments the seed yield of sesame can be increased up to 22 to $33 \%$ or more than that of pollinators excluded condition (Panda et al., 1988). In addition to yield increase, cross-pollination also helps to improve the seed quality through a more unified ripening period and an earlier harvesting time.

By keeping this view in mind the present study was carried out to identify the insects associated with sesame crop during the critical period (flowering phase) in New Alluvial zone of West Bengal and also the impact of pollinators on seed set of sesame crop was assessed.

\section{Materials and Methods}

\section{Experimental Location}

The experiment was conducted during March 2017 to June 2017 at Instructional Farm Jaguli of Bidhan Chandra Krishi Viswavidyalaya at Mohanpur in Nadia district of West Bengal.
The location of the farm is latitude $23.56^{\circ} \mathrm{N}$ and longitude $88.32^{\circ} \mathrm{E}$. The average elevation above the Mean Sea Level (MSL) of the experimental farm is about 9.75 meters.

\section{Experimental design}

The experimental plot was designed in three large plots measuring $12 \times 6 \mathrm{~m}$ each. Then seven small plots measuring $1 \mathrm{~m}^{2}(1 \mathrm{~m} \times 1 \mathrm{~m})$ were selected randomly from each of the large plots, representing replications. The seeds were sown in continuous with row to row spacing of $30 \mathrm{~cm}$ on 15th March, 2017 on each field. Later excess plants were removed to obtain uniform crop stand. All the recommended package of practices was followed for raising a healthy crop.

\section{Diversity of insect pollinators visiting sesame flowers}

The insect species visiting sesame flowers were inspected once in a week from $7.00 \mathrm{am}$ to $5.00 \mathrm{pm}$. The foraging insects were collected by using hand net and sweeping was done at two hours interval throughout the blooming period of the crop starting from 5$10 \%$ flowering. The collected insects were killed and were subsequently identified by using the literatures available.

\section{Relative abundance of insect pollinators on sesame flowers}

The number of insect visitors per square meter area of crop per 2 minutes was recorded from seven randomly selected prescribed areas at around 11 am from which the relative abundance of these insect visitors were calculated by using the formula:

Relative abundance $(\%)=$ (Population of a particular species visiting flowers/ Total population of all species visiting flowers) $\mathrm{x}$ 100 
These observations were started when about 5$10 \%$ of the plants came into bloom and were recorded throughout blooming period of the crop, once every week.

\section{Effect of honey bee (Apis mellifera) pollination on yield attributing parameters and yield of sesame}

For this experiment three large plots measuring 12X6 m each were allotted for each treatment. The three treatments were: T1 Plants with open pollination (Fig. 1); T2 Plants caged with net having only honey bee (Apis mellifera) inside the net as pollinators (Fig. 2); T3 - pollinators excluded (without any pollinators) (Fig. 3). In $\mathrm{T} 1$, the plants were kept open and allowed all the pollinators to visit the flowers. In T2, the entire plot was covered by a large net measuring $12 \mathrm{~m} \times 6 \mathrm{~m} \times$ $4 \mathrm{~m}$ and one 4-frames colony of Apis mellifera in a Nucleus hive was placed inside the net at a height above the crop canopy when about 5 $10 \%$ of flowers have come into bloom. In T3, plants were covered with nets $(1 \mathrm{~m} \times 1 \mathrm{~m} \times 1 \mathrm{~m}$ size) but no hive was placed inside the nets. When the flowering was completed and capsule formation started, the nets and honey bee colonies were removed from the plots.

After maturity, plants from each treatment were harvested and sun dried. Observations were taken on, number of capsules/plant; number of seeds/capsule; 1000 seeds weight (g) and seed yield (kg/ha).

To record the mean number of capsules/plant, 10 plants from each replication were selected randomly. To work out the number of seeds/ capsule, 10 randomly selected capsules from these plants under each of the replications was counted and the mean number (per 10 capsules) was worked out for every replication. The seeds from these capsules were collected to take weight of 1000 seeds weight. The seed yield obtained from each of the replications was later converted into $\mathrm{kg} / \mathrm{ha}$. An increase in seed yield due to open pollination and managed honey bee pollination over pollinators excluded was calculated by using the following formula-

Yield increment $(\%)=($ Yield of honey bee or open pollinated crop -Yield of plot without pollinator) / Yield of plot without pollinator X 100

\section{Results and Discussion}

\section{Diversity of insect pollinators visiting sesame flowers}

The insect species visiting the field of sesame during flowering period of the crop were collected and identified by using available literature and listed in Table 1 along with their systematic position.

Data presented in Table 1 showed that a total number of ten insects belonging to the order of Hymenoptera, Diptera and Lepidoptera were found to visit the flowers of sesame. Among them Hymenopteran insects were predominant comprising of five species from four different families namely Apidae, Megachilidae, Vespidae and Formicidae. The former family (Apidae) consists of two species of honey bees namely, rock bee, Apis dorsata and Itallian bee, Apis mellifera. However, the rest three families were represented eachby single species of insect visitors namely, leaf cutter bee, Megachile sp. (Megachilidae), wasp, Vespa cincta (Vespidae) and ant, Camponotus sericius (Formicidae). On the contrarythree families under the order Lepidoptera and two families under Diptera were recorded during the study. Lepidopteran insects fauna from three families were monarch butterfly, Danaus chrycippus (Nymphalidae), pierid butterfly, Pieris sp. (Pieridae) and amata moth (Amata bicincta) Whereas, flesh fly, Sarcophaga sp. (Sarcophagidae) and common house fly, 
Musca domestica (Muscidae) represented Diptera.

The present findings are in line with the findings of Sanganna et al., (2015) who reported that a total of 14 insect species visited the sesame flower, out of 14 insect species, 10spp. belong to Hymenoptera and 4 to Diptera. Among Hymenopterans, the 4 spp. of honey bees were recorded during flowering period. The present findings are also corroborated by those of Mahfouz et al., (2012), who reported four groups of pollinators visiting sesame belonging to orders Hymenoptera, Diptera, Lepidoptera and Coleoptera during the flowering period and the number of Hymenoptera was highest, followed by Lepidoptera, and then both of Coleoptera and Diptera. In another study Kamel et al., (2013)reported 29 insect species belonging to four groups, 18 of which belonged to Hymenoptera, 7 to Diptera, 3 to Lepidoptera and 1 to Coleoptera during the blooming periodof sesame. These findings are in close agreement with Viraktmath et al., (2001) who studied the relative abundance of pollinator fauna of sesame during two successive seasons. 29 insect species recorded, 15 belonged to Hymenoptera, 8 to Diptera and 6 to Lepidoptera.

\section{Relative abundance of pollinators}

Relative abundance of pollinators per sq.m was recorded on sesame flowers at seven days interval during April and May, 2017 following the methods mentioned earlier. The number of pollinators recorded per sq.m of sesame field is presented in Table 2 and the diagram is shown in Figure 4. On the basis of insect pollinators recorded per square meter during the entire flowering period, Apis dorsata was the most predominant species with an average population of 2.53 insects per sq.m representing $76.39 \%$ of total insect visitors. This was followed by Apis mellifera, the second dominant insect visitor with an average of 0.25 insects per sq.m constituting $7.58 \%$ of insect fauna. The leaf cutter bee, Megachile sp. and Amata bicincta occupying 5.90\% and $3.37 \%$ population of insect visitors with an average of 0.19 and 0.11 insects per sq.m respectively. The dipteran flies in totality were represented by $6.74 \%$ of insect fauna with an average population of 0.22 insects per sq.m. Whereas other insects were occasionally seen to visit the flowers.

It was further observed that, the pollinator population increased with flowering and after reaching a peak period it gradually declined (Fig. 5). The peak population (4.83 insects per sq.m) was observed on 6th May, 2017during peak period of flowering.

Later it declined with the decline in number of flowers and capsule development. The average number of insects per sq.m during the flowering period was 3.19.

Similar results were documented by Kamel $e t$ al., (2013)where it had been shown that the percentage of Hymenoptera was higher in both the seasons of study and it were $90.94 \%$ and $89.59 \%$, sequentially which were followed by Diptera $(3.93 \%$ and $5.38 \%)$, Lepidoptera (3.58\% and 3.62), and Coleoptera (1.53\% and $1.39 \%$ )during the entire blooming period of sesame.

\section{Effect of honey bee pollination on yield and yield attributing parameters}

Under field condition the effect of honey bee pollination on seed yield and yield attributing parameters of sesame was studied in comparison with open pollination and pollinator excluded. Following yield attributing parameters were recorded during the course of study:

- $\quad$ Number of capsules /plant

- $\quad$ Number of seeds /capsule 
- $\quad 1000$ seed weight (gm.)

From these parameters the seed yield (kg/ha) was calculated. Furthermore an increase in \% seed yield in open and honey bee pollination over pollinator excluded crop had been calculated. The findings are represented in the Table 3.

The average number of capsules per plant was found to be highest (41.57 capsules/plant) in open pollination followed by honey bee $(A$. mellifera) pollination (38.85 capsules /plant). On the contrary, it was only 28.71 capsules/plant in pollinators excluded. It was further observed that open pollinated and honey bee (A. mellifera) pollinated plot showed significant difference in respect of average no. of capsules/plant.

The data recorded on mean number of seeds per capsule revealed that mean number of seeds per capsule (50.85 seeds/capsule) was higher in open pollinated plot followed by plot caged with $A$. mellifera colony (49.14 seeds/capsule) and the least number of seeds per capsule (38.14 seeds/capsule) was recorded in pollinators excluded. It was also observed that open pollinated and honey bee (A. mellifera) pollinated plot showed no significant difference i.e., these treatments were statistically at par.

The highest mean 1000 seed weight was recorded in open pollinated $(3.10 \mathrm{gm})$ plot followed by $A$. mellifera $(2.89 \mathrm{gm})$, whereas the lowest mean 1000 seed weight was recorded in pollinators excluded (2.56 gm). Significant difference was also observed between open and honey bee pollinated plot.

The impact of different modes of entomophilous pollination showed that highest seed yield was obtained in open pollinated $(835.14 \mathrm{~kg} / \mathrm{ha})$ plot followed by A. mellifera $(784.71 \mathrm{~kg} / \mathrm{ha})$ pollination. However, the lowest yield among the treatments was obtained from pollinators excluded plot $(580.28 \mathrm{~kg} / \mathrm{ha})$. The above data revealed that open and honey bee (A. mellifera) pollination showed clear increment in seed yield in comparison to pollinators excluded. The percentage yield increase of the former two treatments was calculated over pollinators excluded condition following the method discussed earlier. The highest percentage yield increase was observed in open pollination (43.92\%) followed by A. mellifera (35.23\%) pollination.

The answer behind the effect of better result in open pollination over A. mellifera pollination may lie in the fact that in open condition the flowers were visited by composite natural pollinators, whereas in net pollinated condition only A. mellifera visited the flowers as pollinator. As well as the number of total pollinators in open condition was found higher than the net pollinated condition throughout the study period (Table 4). Hence the spatiotemporal variation of different pollinators attend better pollination of flowers in open condition over net pollinated, leads to better result in open condition.

The results of present investigation are in conformity with the earlier recorded observations of Mahmoud (2012)who reported that sesame plants exposed to insects visit had significantly higher quantity and quality yield compared to plants from which insects were excluded during course of study. Similar observations were also recorded by Rahman (2014) who studied the impact of different modes of pollination in sesame and reported that both open and caged pollination with honey bee significantly increased the no. of capsule per plant, no. of seeds per capsule and thousand seed weight (g) as compared to pollinators excluded condition and the highest yield was obtained in caged with honey bee pollination (1.16 t/ha) followed by open 
pollination (1.03 t/ha) with no significant of sesame can be increased upto 22 to $33 \%$ or difference. In an another study Panda et al., more than that of pollinators excluded (1988) reported that both in open pollination condition.

and bee pollination treatments the seed yield

Table.1 List of different insects visiting sesame flowers during study

\begin{tabular}{|l|l|l|l|l|}
\hline $\begin{array}{l}\text { Sl. } \\
\text { No. }\end{array}$ & Common name & Scientific name & Family & Order \\
\hline $\mathbf{1 .}$ & Rock bee & Apis dorsata & Apidae & Hymenoptera \\
\hline $\mathbf{2 .}$ & Itallian bee & Apis mellifera & Apidae & Hymenoptera \\
\hline $\mathbf{3 .}$ & Leaf cutter bee & Megachile sp. & Megachilidae & Hymenoptera \\
\hline $\mathbf{4 .}$ & Wasp & Vespa cincta & Vespidae & Hymenoptera \\
\hline $\mathbf{5 .}$ & Ant & $\begin{array}{l}\text { Camponotus } \\
\text { sericius }\end{array}$ & Formicidae & Hymenoptera \\
\hline $\mathbf{6 .}$ & Monarch butterfly & Danaus chrycippus & Nymphalidae & Lepidoptera \\
\hline $\mathbf{7 .}$ & Pierid butterfly & Pieris sp. & Pieridae & Lepidoptera \\
\hline $\mathbf{8 .}$ & $\begin{array}{l}\text { Amata moth/nine } \\
\text { spotted moth }\end{array}$ & Amatabicincta & Arctiidae & Lepidoptera \\
\hline $\mathbf{9 .}$ & Flesh fly & Sarcophaga $s p$. & Sarcophagidae & Diptera \\
\hline $\mathbf{1 0 .}$ & Common House fly & Musca domestica & Muscidae & Diptera \\
\hline
\end{tabular}

Table.2 Observations for abundance of different pollinators persq.m in sesame

\begin{tabular}{|l|l|l|l|l|l|l|l|l|}
\hline Date & $\mathbf{2 2 . 4 . 1 7}$ & $\mathbf{2 9 . 4 . 1 7}$ & $\mathbf{6 . 5 . 1 7}$ & $\mathbf{1 3 . 5 . 1 7}$ & $\mathbf{2 0 . 5 . 1 7}$ & Total & Average & $\begin{array}{l}\text { Mean } \\
\text { population }\end{array}$ \\
\hline A.dorsata & 1.42 & 3.71 & 3.57 & 2.71 & 1.28 & 12.69 & 2.53 & 76.39 \\
\hline A. mellifera & 0.14 & 0.28 & 0.42 & 0.14 & 0.28 & 1.26 & 0.25 & 7.58 \\
\hline Megachilesp. & 0.00 & 0.28 & 0.42 & 0.14 & 0.14 & 0.98 & 0.19 & 5.90 \\
\hline Dipteran flies & 0.28 & 0.14 & 0.28 & 0.28 & 0.14 & 1.12 & 0.22 & 6.74 \\
\hline Amatabicincta & 0.00 & 0.14 & 0.14 & 0.00 & 0.28 & 0.56 & 0.11 & 3.37 \\
\hline Total & 1.84 & 4.55 & 4.83 & 3.27 & 2.12 & 16.61 & & \\
\hline
\end{tabular}

Table. 3 Change in yield through honey bees and open pollination

\begin{tabular}{|c|c|c|c|c|c|}
\hline & $\begin{array}{l}\text { Number of } \\
\text { capsules/plant }\end{array}$ & $\begin{array}{l}\text { Number of } \\
\text { seeds/capsule }\end{array}$ & $\begin{array}{l}1000 \text { Seed } \\
\text { Wt.(gm.) }\end{array}$ & $\begin{array}{l}\text { Projected Seed } \\
\text { Yield(kg/ha) }\end{array}$ & $\begin{array}{l}\% \text { increase in } \\
\text { yield }\end{array}$ \\
\hline $\begin{array}{l}\text { Open pollination } \\
\text { nation }\end{array}$ & $\begin{array}{l}41.57 \\
(6.52)^{*}\end{array}$ & $\begin{array}{l}50.85 \\
(7.20)^{*}\end{array}$ & $\begin{array}{l}3.10 \\
(2.02)^{*}\end{array}$ & 835.14 & 43.92 \\
\hline $\begin{array}{l}\text { Honey bee }(A . \\
\text { mellifera }) \text { pollination }\end{array}$ & $\begin{array}{l}38.85 \\
(6.31)^{*}\end{array}$ & $\begin{array}{l}49.14 \\
(7.08)^{*}\end{array}$ & $\begin{array}{l}2.89 \\
(1.97)^{*}\end{array}$ & 784.71 & 35.23 \\
\hline $\begin{array}{l}\text { Without any } \\
\text { pollinator }\end{array}$ & $\begin{array}{l}28.71 \\
(5.44)^{*}\end{array}$ & $\begin{array}{l}38.14 \\
(6.25)^{*}\end{array}$ & $\begin{array}{l}2.56 \\
(1.88)^{*}\end{array}$ & 580.28 & \\
\hline SE(m) & 0.041 & 0.038 & 0.008 & 0.006 & \\
\hline CD at $5 \%$ & 0.129 & 0.119 & 0.024 & 0.017 & \\
\hline
\end{tabular}

\footnotetext{
*Square root transformed values in parenthesis
} 
Table.4 Population of insect fauna in open and honey bee (A. mellifera) pollination

\begin{tabular}{|c|c|c|c|c|c|c|}
\hline Date & A. dorsata & $\begin{array}{l}\text { A. } \\
\text { mellifera }\end{array}$ & $\begin{array}{l}\text { Megachile } \\
\text { sp. }\end{array}$ & Others & $\begin{array}{l}\text { Total } \\
\text { outside net }\end{array}$ & $\begin{array}{l}\text { A. mellifera } \\
\text { in net }\end{array}$ \\
\hline 22.04 .17 & 1.42 & 0.14 & 0.00 & 0.28 & 1.84 & 2.14 \\
\hline 29.04.17 & 3.71 & 0.28 & 0.28 & 0.28 & 4.55 & 3.21 \\
\hline 06.05.17 & 3.57 & 0.42 & 0.42 & 0.42 & 4.83 & 3.57 \\
\hline 13.05.17 & 2.71 & 0.14 & 0.14 & 0.28 & 3.27 & 2.12 \\
\hline 20.05.17 & 1.28 & 0.28 & 0.14 & 0.42 & 2.12 & 1.42 \\
\hline
\end{tabular}

Fig.1\&2 Open pollination \& Honey bee (A. mellifera) pollination
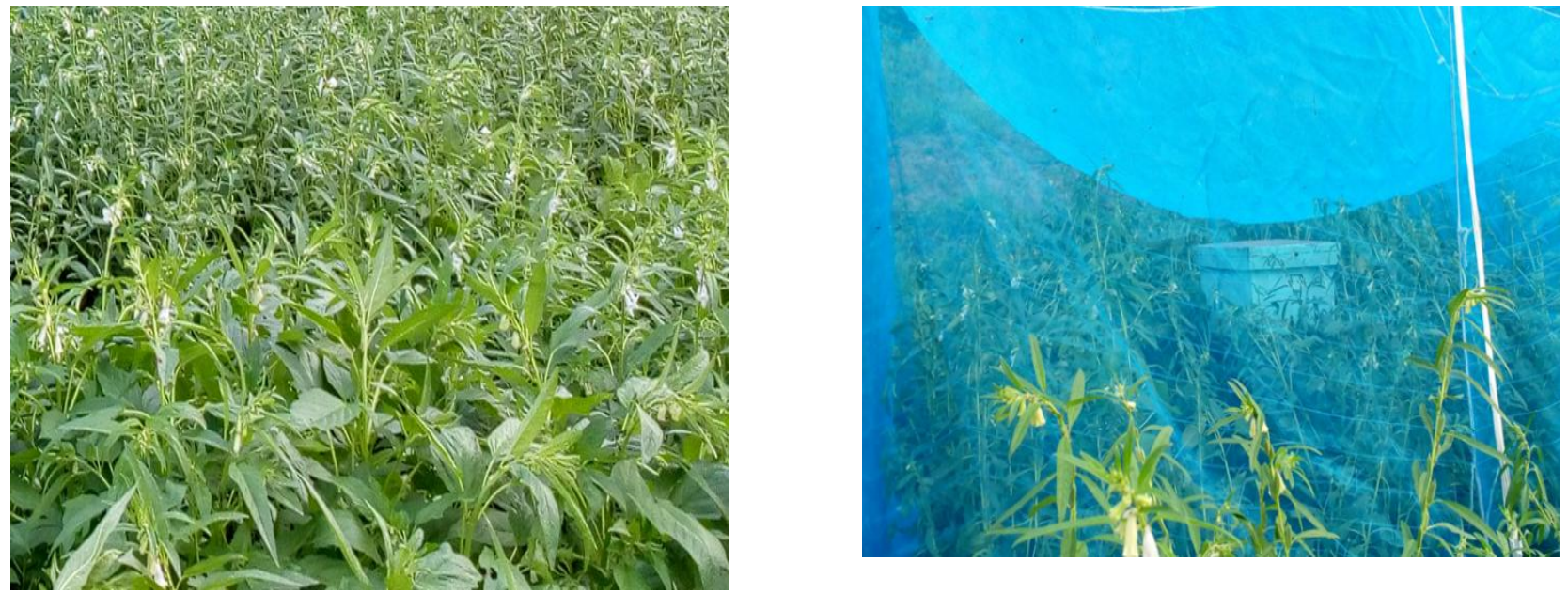

Fig.3 pollinators excluded (without any pollinators)

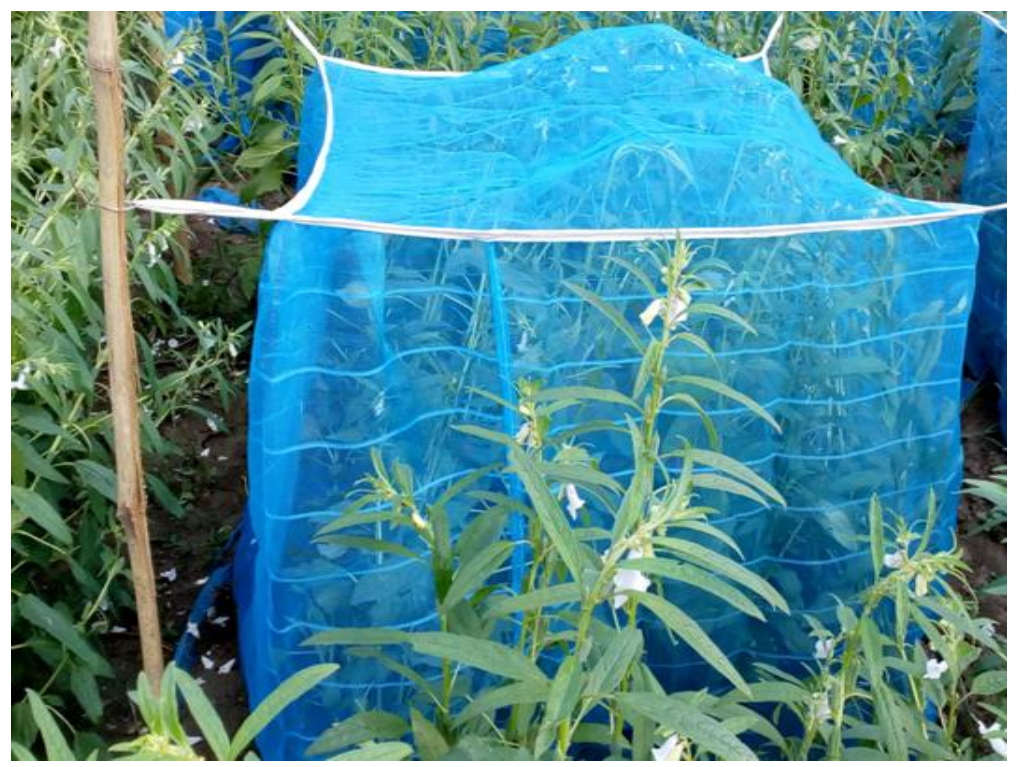


Fig.4 Abundance of insect pollinators (percentage of insect fauna/ sq.m/2 min.)

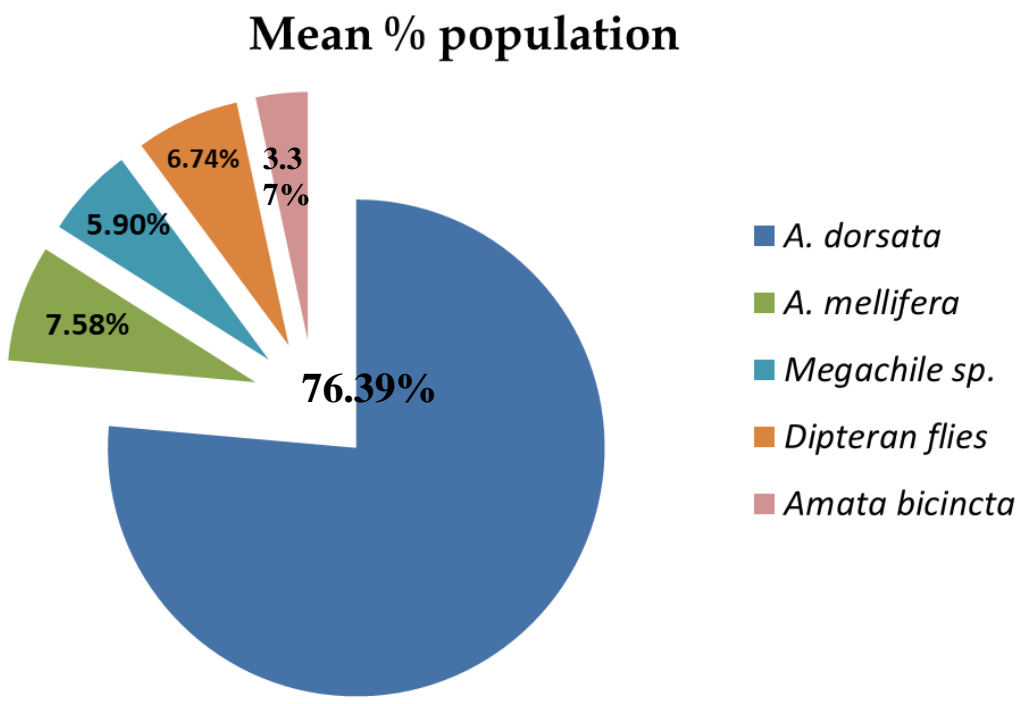

Fig.5 Population of different pollinators during different date of observations

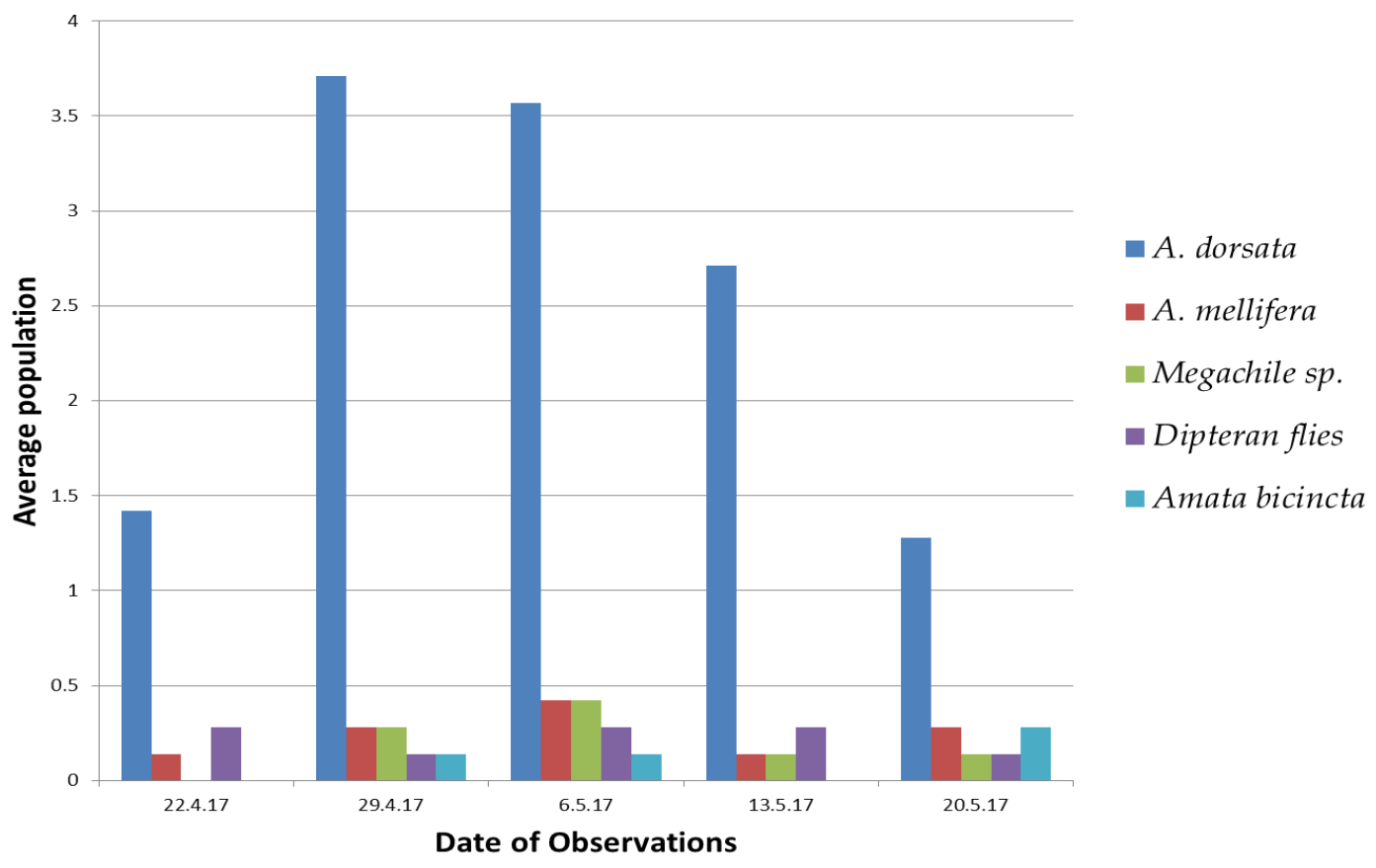

In conclusion, the present investigation showed that a total number of thirteen insect species from three different orders viz. Hymenoptera, Diptera and Lepidoptera found to visit the sesame flowers. Hymenopterans pollinators $(89.87 \%)$ were dominant amongst various pollinators and $A$. dorsata and $A$. mellifera being dominant. Whereas, Dipteran pollinators $(6.74 \%)$ were the second dominant followed by Lepidoptera $(3.37 \%)$ during the blooming period of the crop. Both in open pollination and honey bee pollination the number of capsules/plant, number of seeds/capsule, 1000 seed weight and seed yield of sesame significantly increased as compared to plots without any pollinators. 
The highest seed yield was obtained in open pollinated (835.14 kg/ha) plot and the lowest one was observed in pollinators excluded plot $(580.28 \mathrm{~kg} / \mathrm{ha})$. The percentage yield increase over pollinators excluded were $43.92 \%$ and $35.23 \%$ inopen and A. mellifera pollination respectively.

\section{Acknowledgement}

The authors sincerely acknowledge to AICRP (Honey Bees and Pollinators) for providing financial and technical facilities to carry out the present investigation.

\section{References}

Ashri, A. 2007. Sesame (Sesamumindicum L.). In: Genetic Ressources, Chromosome Engineering and Crop Improvement, Singh, R.J. (Ed.). Vol. 4. Oilseed crops. CRC Press, Boc Raton, FL., pp. 231- 289.

Dafni, A. and Kevan, P.G. 2005. Practical pollination biology. Enviroquest, 20: 114- 128.

Free, J.B. 1993. Insect Pollination of Crops. Academic Press. London UK, pp. 684.

Jivan, A. 2013. The Impact of Pesticides on Honey Bees and Hence on Humans. Scientific Papers Animal Science and Biotechnologies 46(2): 272-277.

Kamel, S.M., Blal, A.H., Mahfouz, H.M. and Said, M. 2013.The most common insect pollinator species on sesame crop (Sesamum indicum L.) in Ismailia Governorate, Egypt. Arthropods, 2(2): 66-74.

Kearns, C.A., Inouye, D.W. and Waser, N.M. 1998.Endangered mutualism: The conservation of plant pollinator interactions. Ann. Rev. Eco. Evo. Syste., 29: 83-112.

Kumar, R. and Lenin, J.K. 2000. Insect pollinators and effects of cross pollination on yield attributes of sesame
(Sesamum indicum L.). Indian Bee Journal, 62 (1-2): 75-80.

Mahfouz, H.M., Kamel, S.M., Belal, A.H. and Said, M. 2012. Pollinators visiting sesame (Sesamum indicum L.) seed crop with reference to foraging activity of some bee species. Cercetări Agronomiceîn Moldova, 45(2):150.

Mahmoud, F.M. 2012. Insects Associated with Sesame (Sesamun indicum L.) and the Impact of Insect Pollinators on Crop Production. Pestic. Phytomed. (Belgrade), 27(2): 117-129.

Mitra, B., Banerjee, D., Mukherjee, M., Bhattacharya, K. and Parui, P. 2008. Flower visiting flies (Diptera: Insecta) of Kolkata and Surroundings, (Pictorial handbook). India: Zoological Survey of India (ZSI), Kolkata.

Mitra, B. and Parui, P. 2002. New record of entomofauna from Thar Desert. Insect Environ., 8: 115-116.

Panda, P., Sontakke, B.K. and Sarangi, P.K. 1988.Preliminary studies on the effect of bee (Apis ceranaindica Fab.) pollination on yield ofsesamum and niger. Indian Bee Journal, 50: 63-64.

Rahman, Z. 2014. Effect of bee pollination on the yield of sesame (Sesamum indicum L.). M. Sc. Thesis, Sher-e-Bangla Agricultural University, Dhaka, Bangladesh.

Robinson, W.E. and Morse, R.A. 1989. The value of honeybees as pollinators of US crops. American Bee Journal, 129(1): 477-487.

Said, F., Inayatullah, M., Ahmad, S., Iqbal, T., and Shah, R. A. 2015. Foraging behavior of the Himalayan Honeybee, Apis cerana (Hymenoptera: Apidae) associated with sunflower (Helianthus annuus L.) at Peshawar District of Khyber Pakhtunkhwa (KP). Journal of Entomology and Zoology Studies 3(3): 203-207.

Sanganna, M.S. and Eswarappa, G. 2015. 
Sesame (Sesamum indicum L.) Crop Insect Pollinators with Special Reference to the Foraging Activity of Different Species of Honeybees. IOSR Journal of Agriculture and Veterinary Science (IOSR-JAVS), 8(11): 09-14

Sarker, A.M. 2004.Effect of honeybee pollinisation on the yield of rapeseed, mustard and sesame. Geobros (jodhpur), 31: 49-51.

Viraktmath, S.A., Patil, B., Murasing, S. and
Guruprasad, G.S. 2001. Relative abundance of pollinator fauna of cross pollinated oilseed crops at Dharwad in Karnataka (India). Indian Bee Journal, 63(3-4): 64-67.

Yermanos, D.M. 1980.Sesame. In: Hybridization of Crop Plants, Fehr, H. and H. Hadleys (Eds.). Agronomy-crop Science Society of America, Madison, WI., pp. 549-563.

\section{How to cite this article:}

Rakesh Das and Shantanu Jha. 2019. Insect Pollinators of Sesame and the Effect of Entomophilous Pollination on Seed Production in New Alluvial Zone of West Bengal. Int.J.Curr.Microbiol.App.Sci. 8(03): 1400-1409. doi: https://doi.org/10.20546/ijcmas.2019.803.164 